
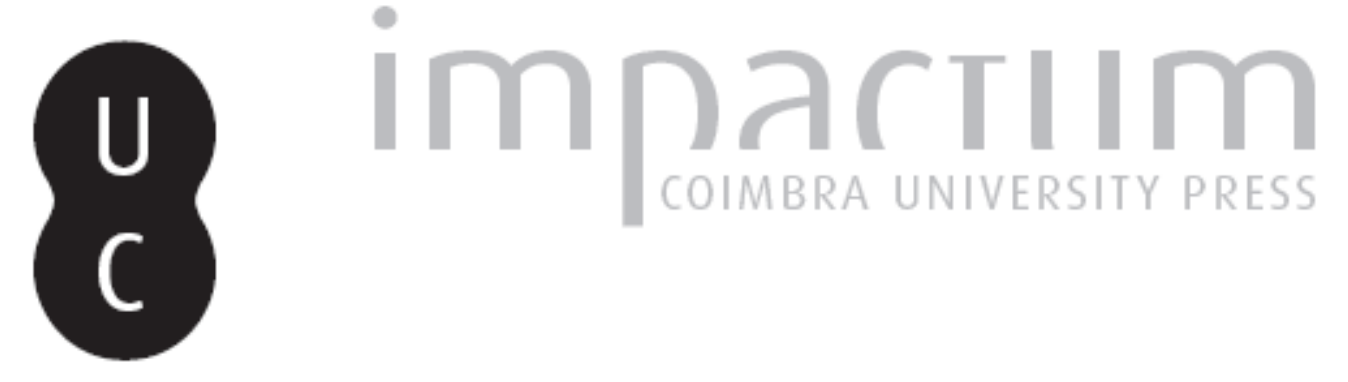

\title{
25 de Abril de 1974: uma revolução imperfeita
}

Autor(es): $\quad$ Ferreira, José Medeiros

Publicado por: Imprensa da Universidade de Coimbra

URL persistente:

URI:http://hdl.handle.net/10316.2/45081

DOI:

DOI:https://doi.org/10.14195/2183-8925_7-2_12

Accessed : $\quad$ 26-Apr-2023 01:18:36

A navegação consulta e descarregamento dos títulos inseridos nas Bibliotecas Digitais UC Digitalis, UC Pombalina e UC Impactum, pressupõem a aceitação plena e sem reservas dos Termos e Condições de Uso destas Bibliotecas Digitais, disponíveis em https://digitalis.uc.pt/pt-pt/termos.

Conforme exposto nos referidos Termos e Condições de Uso, o descarregamento de títulos de acesso restrito requer uma licença válida de autorização devendo o utilizador aceder ao(s) documento(s) a partir de um endereço de IP da instituição detentora da supramencionada licença.

Ao utilizador é apenas permitido o descarregamento para uso pessoal, pelo que o emprego do(s) título(s) descarregado(s) para outro fim, designadamente comercial, carece de autorização do respetivo autor ou editor da obra.

Na medida em que todas as obras da UC Digitalis se encontram protegidas pelo Código do Direito de Autor e Direitos Conexos e demais legislação aplicável, toda a cópia, parcial ou total, deste documento, nos casos em que é legalmente admitida, deverá conter ou fazer-se acompanhar por este aviso.

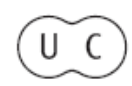




\section{REVISTA DE HISTORIA DAS IDEIAS 7}

\section{REVOLTAS E REVOLUCOẼS}

\section{**}

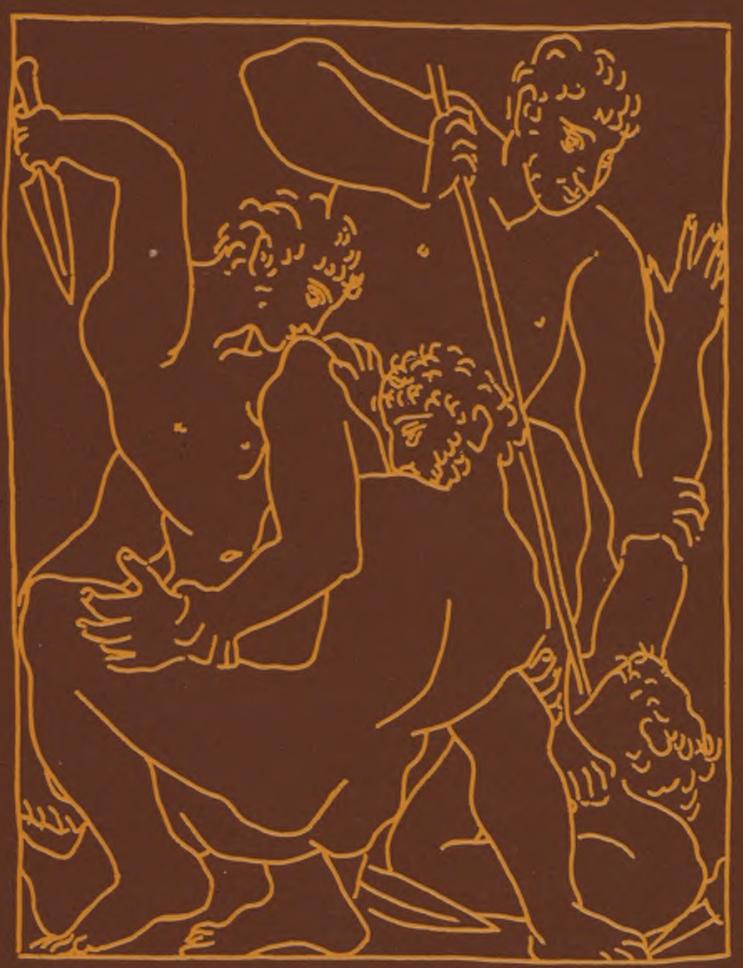

INSTITUTO DE HISTÓRIA E TEORIA DAS IDEIAS FACULDADE DE LETRAS 


\section{DE ABRIL DE 1974: UMA REVOLUÇÃO IMPERFEITA}

Analisar o derrube da ditadura quase cinquentenária, ocorrido em 25 de Abril de 1974, numa perspectiva de «revoluções portuguesas comparadas», como resulta do projecto em boa hora levado a cabo pela Revista de História das Ideias, não é tarefa simples.

Em primeiro lugar, pela sua actualidade. De certa maneira, ainda é a revolução do 25 de Abril que estamos a viver. Daí que me tenha remetido de preferência à análise dos acontecimentos pré-constitucionais, adoptando uma periodização formal mas segura. Julgo assim ficar ao abrigo de qualquer mudança na natureza da revolução que se venha a verificar, implicando novas interpretações. Não será pertinente recordar que a revolução liberal de 1820 só pode ser bem entendida pelos eventos da guerra civil subsequente e pela vitória de 1834? O título «uma revolução imperfeita», destina-se, pela sua ambivalência, a cobrir a falta de perspectiva histórica.

Em segundo lugar, porque, tratando-se de um trabalho para ser publicado na Revista de História das Ideias, sempre se há-de querer saber quais as doutrinas e as influências que presidiram à movimentação revolucionária. Em termos interrogativos: a revolução de 25 de Abril de 1974 é a última das transformações europeias da série inaugurada com a derrota militar dos regimes autoritários conservadores no decurso da II Guerra Mundial, ou ela é a anunciadora de outro ciclo de revoluções?

Para responder a essas dificuldades, optei, com certa singeleza, por colocar em evidência a grande novidade da revolução ${ }^{(*)}$

\section{Nova de Lisboa. \\ (*) Faculdade de Ciências Sociais e Humanas da Universidade}


do 25 de Abril, a qual é, o papel desempenhado pela estratégia da instituição militar no derrube da ditadura, na descolonização, nas mudanças sociais e económicas, no estabelecimento do poder local e das autonomias regionais. Sobretudo acentuei a sua capacidade para pilotar o trânsito entre o derrube da ditadura e o estabelecimento de um regime constitucional de democracia política. Mas uma revolução conduzida por um «corpo de Estado» teria que ser imperfeita pela necessidade de equilibrar as rupturas com uma linha de continuidade institucional.

Ora, uma revolução conduzida por um corpo de Estado e não por grupos sociais ou por partidos políticos com vocação insurreccional é matéria mais do que suficiente para dar aos acontecimentos de Abril de 1974 um lugar singular na história das revoluções.

Disso mesmo já se aperceberam muitas Universidades estrangeiras que promovem consecutivos seminários, colóquios e conferências sobre a revolução do 25 de Abril, o que demonstra o conteúdo universal da história contemporânea de Portugal e a possibilidade de tornar matéria tão actual objecto histórico analisável.

Entre nós não tem sido fácil às universidades anexar tal matéria de estudo. Como digo no vestíbulo do livro Ensaio Histórico sobre a Revolução de 25 de Abril:

\begin{abstract}
«....a história da contemporaneidade não usufrui de completa dignidade académica. Fora alguns exemplos meritórios e corajosos de universitários portugueses que se dedicaram científicamente a temas do século XX (principalmente respeitantes à compreensão da I República e à sua queda), a maior parte da produção científica sobre a sociedade portuguesa contemporânea tem sido obra de sociólogos, geógrafos ou politólogos. Os historiadores parecem evitar a contemporaneidade talvez por avaliarem, no seu justo alcance, a utilidade marginal de tal esforço».
\end{abstract}

Este último aspecto foi ultrapassado pelo critério da $R e$ vista de Histórias das Ideias ao resolver incluir, nos volumes dedicados ao tema «Revoltas e Revoluções», o 25 de Abril de 1974, o que constitui valioso estímulo aos historiadores da contemporaneidade.

\title{
I. A ORIGINALIDADE DA REVOLUÇÃO DO 25 DE ABRIL
}

De uma maneira geral a instituição militar alheou-se dos regimes políticos em Portugal e a sorte destes foi-lhe indiferente. Basta mencionar o trânsito entre a Monarquia constitucional e a República para evidenciar esta asserção. 
Subordinada ao poder politico da monarquia constitucional, a instituição militar, saída do «Exército Libertador» vencedor da guerra civil contra os miguelistas terminada em 1834, não a defende e estabelece de imediato boas relações com a República implantada em 1910, boas relações que se irão manter pelo menos até à eclosão da I Guerra Mundial e aos movimentos do general Pimenta de Castro em 1915 e de Sidónio Pais em Dezembro de 1917.

$\mathrm{O}$ mito de que as Forças Armadas tiveram um comportamento caracterizado por uma série de pronunciamentos durante todo o séc. XIX e princípios do séc. XX não resiste a uma análise histórica. Desde o último acto de Saldanha em 1870, aliás esporádico e efémero, que a instituição militar não tinha qualquer interferência significativa na vida política portuguesa. Mesmo as reacções ao «ultimatum» inglês têm uma expressão eminentemente civil.

Por outro lado, as intervenções militares na sociedade portuguesa, durante o séc. XX, e apenas considerando as intervenções de carácter institucional, tiveram todas características diferentes entre si.

Para caracterizar estas diferenças basta analisar as atitudes das Forças Armadas face aos diferentes regimes políticos que vigoraram em Portugal neste século. Desde a efectiva subordinação das Forças Armadas à Monarquia constitucional, ao seu alheamento no trânsito entre a monarquia e a república em 1910, passando pelo aproveitamento castrense da doutrina militar da 1. ${ }^{a}$ República até ao desentendimento visível com o regime parlamentar republicano, após o início da I Guerra Mundial, que iria culminar no movimento de 28 de Maio de 1826, vários são os comportamentos da instituição militar. Mas de uma forma geral pode-se detectar um continuado alheamento face à natureza do regime político.

O movimento de 28 de Maio foi precedido por um lento processo de fortalecimento da unidade de intervenção da instituição militar no domínio político, ocorrido entre 1918 e 1926. Para tal unidade muito contribuiu a forma como a instituição militar passou a ser olhada «de fora», nomeadamente por certos intelectuais como André Brun, Fidelino Figueiredo, Fernando Pessoa e os próprios «Seareiros», cuja revista, logo nos primeiros números, inclui colaboração de vários militares, entre os quais Gomes da Costa.

De facto, o período que se estende entre 1919 e 1926 será caracterizado por uma intervenção cada vez mais institucional dos militares contra o Partido Democrático.

Porém, essa intervenção dos militares contra o Partido Democrático nem sequer tinha um objectivo anti-republicano 
preciso, mantendo-se pois as Forças Armadas alheadas das questões do regime politico.

O programa da Ditadura Militar de 1926 não ia além da proclamação da necessidade de ordem e de moralização e eficácia na administração pública. Daí que, sem doutrina sobre que tipo de regime político iria nascer da transitória ditadura militar, esta será anexada por uma ditadura civil cujo principal protagonista foi Salazar. Este ainda se defronta com o general Vicente Ferreira e com as reticências de alguns comandantes de unidades preocupados com o resultado do plebiscito de Março de 1933 ao qual se opõem; mas Salazar distingue-se exactamente por ter uma arquitectura institucional para o regime político resultante da ditadura militar. Paradoxalmente os militares não a encontram.

Ora o Movimento das Forças Armadas, em 1974, apresenta desde logo no seu Programa, como objectivo concreto e prioritário, atingir a restauração da democracia. Pela primeira vez neste século, uma revolução militar era acompanhada de uma opção clara por um certo tipo de regime político.

Esta é uma diferença específica, essencial, entre o M.F.A. e outras intervenções castrenses em Portugal.

Vejamos a sua explicação.

Como tive ocasião de dizer em 1973:

«Se se enquadrar os problemas portugueses à luz da continuação de Portugal no Mundo, pode aparecer subalternizado o papel dos instrumentos capazes de levarem para a frente o projecto de continuar a Nação. Porém, se prescrutarmos os anseios internos do corpo nacional torna-se evidente que a união dos portugueses se faz em torno da conquista das principais liberdades democráticas. A instauração de formas democráticas será pois exigência que um verdadeiro poder antifascista e anti-colonialista não poderá adiar.

Na realidade, a permanência do regime do Estado Novo gerou no seio da sociedade portuguesa um profundo movimento de aspiração à prática das liberdades públicas sempre negadas pela sua política terrorista. Criou-se assim, em torno das liberdades democráticas, um elemento ideológico fortíssimo que tem expressão nacional e é interelassista. Nenhum plano para a nação poderá ladear este problema propriamente político» 0 ).

C) José Medeiros Ferreira, Da Necessidade de um Plano para a Nação, 3. ${ }^{\circ}$ Congresso da Oposição Democrática, teses, volume sobre a Situação e Perspectiva Política no Plano Nacional e Internacional, Lisboa, Ed. Seara Nova, 1974, p. 17. 
Ora, o M.F.A. deve ser visto como uma metamorfose da instituição militar e desta forma o seu objectivo de estabelecer em Portugal um regime de democracia política corresponde ao pensamento estratégico daquela.

Essa acção ao nível da estratégia geral poderá ser melhor compreendida caso a compararmos «mutati mutandis» aos métodos políticos empregados, após a II Guerra Mundial, pelas forças aliadas vencedoras, quer nos teatros europeus quer no teatro asiático, nomeadamente na Itália, na Alemanha e no Japão. Com a diferença substancial de, no caso do M.F.A., ser um exército nacional, num território não invadido, a introduzir a mudança entre um regime ditatorial e um regime de democracia política $\left({ }^{2}\right)$.

A institucionalização do M.F.A., ou seja, a sua formalização como agente político participando em órgãos de soberania, salvaguardava ainda as Forças Armadas do empenhamento político necessário para se proceder ao trânsito entre a ditadura e a democracia política.

A estratégia militar, ou a simples conduta, também foi actuante na caracterização dos governos provisórios e por aí também se distingue das outras intervenções.

Assim, enquanto no golpe de Estado saído do 28 de Maio de 1926 os militares optaram por um regime ditatorial (Ditadura Militar entre 1926 e 1928; Ditadura Nacional 1928-1933), já no 25 de Abril de 1974, o período de concentração de poderes ditatoriais pelos militares foi extremamente curto: mais precisamente durou 3 semanas até à aprovação da Lei $3 / 74$ e à constituição do I Governo Provisório a 14 de Maio.

Mas se o Governo Provisório era de natureza civil já o programa do M.F.A. não falava de legalização imediata de partidos políticos. O «civilismo» do Programa não era obrigatoriamente sinónimo de regime de partidos.

Com efeito no Programa do M.F.A. não há qualquer referência à legalização dos partidos políticos nem deles se fala no conjunto das «medidas imediatas». A possível formalização de partidos era tarefa para futuro governo provisório. No capítulo B - Medidas a curto prazo, pode ler-se no ponto 5:

«O Governo Provisório, tendo em atenção que as grandes reformas de fundo só poderão ser adoptadas no âmbito da

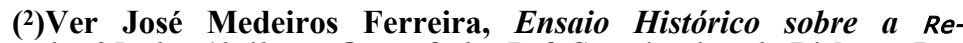
volução do 25 de Abril - O período Pré-Constitucional, Lisboa, Imprensa Nacional - Casa da Moeda, 1983. 


\section{Revoltas e Revoluções}

futura Assembleia Nacional Constituinte, obrigar-se-á a promover imediatamente:

a) $[\ldots]$

b) A liberdade de reunião e de associação».

Em aplicação deste princípio será permitida a formação de «associações políticas» possíveis embriões de futuros partidos, e garantida a liberdade sindical, de acordo com lei especial que regulará o seu exercício $\left(^{3}\right)$.

Mas a formalização dos partidos políticos, prevista, na melhor das hipóteses, para a Assembleia Constituinte, acabou por se realizar em dois tempos bem mais curtos: o primeiro, com a chegada a Portugal dos dois secretários-gerais, Mário Soares e Álvaro Cunhal e a entrada de ambos no $1 .^{\circ}$ Governo Provisório; o segundo tempo com a aprovação da lei dos partidos em Outubro de 1974 em que se atribui a estes o monopólio da actividade eleitoral.

A formação do $1 .^{\circ}$ Governo Provisório será pois um processo político bem mais complexo e importante para caracterizar a natureza do novo regime político do que normalmente se julga.

Ou seja, embora os militares tivessem optado, aquando da aprovação do programa do M.F.A., pelo estabelecimento de um regime democrático pluralista e pela formação rápida de um governo provisório de natureza civil, já o preenchimento desse governo provisório e a existência de partidos políticos como instrumentos característicos da fase seguinte da vida política nacional eram incógnitas a resolver ou vazio estratégico a ser preenchido por acções de conduta.

Mário Soares relata-nos dois momentos do seu primeiro contacto com o general Spínola deveras interessantes para situar o estado da questão nos dias seguintes ao derrube da ditadura.

Num trecho do livro Portugal: Que Revolução relata-nos Mário Soares este diálogo ocorrido a 27 de Abril: «Spínola apareceu. Abraçámo-nos espontaneamente e uns momentos depois convidou-me a entrar no seu gabinete: «A revolução está feita. Sinto-me feliz por o receber» — foram as suas primeiras palavras» $\left({ }^{4}\right)$. Relato que completa mais tarde da seguinte forma: «Ele (o general Spínola) recebeu-me a título de exilado antifascista, mas eu fiz questão de acentuar e de repetir, que estava ali na qualidade de Secretário-Geral do Partido Socialista. Preocupei-me em acentuar o vector pluripartidário do

(3) Ver programa do Movimento das Forças Armadas, Lisboa, Imprensa Nacional, 1974.

(4) Mário Soares, Portugal - Que Revolução? 1976, p. 26. 
nosso regime.... pois considerava ambígua a linguagem de alguns militares, que não falavam em partidos políticos....» (5).

Pelo seu lado, a 29 de Abril, o dirigente comunista Octávio Pato envia ao Secretariado do Comité Central uma carta em que afirma prudentemente: «que neste momento já não foi só o Governo mas também o fascismo que foram derrubados» e opina que o Partido Comunista «está à beira da legalidade». De qualquer maneira «neste momento há já vários camaradas funcionários que passaram à legalidade» $(\mathrm{G})$.

Casuística quanto ao reconhecimento imediato dos partidos políticos. Casuística quanto à natureza do $1 .^{\circ}$ Governo Provisório conforme nos revelam eventos já conhecidos:

«Logo a 30 de Abril, e em casa de Veiga Simão, segundo Alberto Machado, reunem-se estes com Adelino Amaro da Costa, Alberto Ralha, Vítor Crespo, entre outros. Spínola aceitará a substância do Programa que será incluído no executivo da responsabilidade do Professor Palma Carlos, mas irá decidir-se por um Governo Provisório de natureza pluripartidária e não de independentes. Logo se verá que mais importante do que a aceitação do Programa (do MFA) era a natureza do Governo Provisório e que o poder político decorrente da Revolução do 25 de Abril estaria essencialmente dependente da formação e da natureza do $1 .^{\circ}$ Governo Civil» $\left({ }^{(7)}\right.$.

Por estes testemunhos, se pode verificar a indeterminação real sobre o papel dos partidos políticos no período imediatamente posterior à formação da Junta de Salvação Nacional. Também se pode evidenciar a existência de um «écran» entre os militares do M.F.A. e aqueles políticos, «écran» constituído por essa mesma Junta de Salvação Nacional.

No entanto muito rapidamente os partidos políticos passam a constituir o veículo privilegiado da evolução política.

Vejamos como e porquê.

As Forças Armadas necessitavam de promover a consolidação de um regime de democracia política que lhes assegurasse o ambiente necessário à sua re-adaptação na sociedade portuguesa. A instituição militar necessitava de assegurar a sua manutenção para além das vicissitudes do seu empenha-

(5) Expresso - Revista do 25 de Abril de 1981.

(6) Carta de Octávio Pato ao Secretariado do Comité Central, datada de 29 de Abril de 1974, exposta no Pavilhão dos Desportos em Maio de 1981, na Exposição Comemorativa do P.C.P..

(7) José Medeiros Ferreira, Ensaio Histórico sobre a Revolução do 25 de Abril - $\mathrm{O}$ Período $\mathrm{Pr}^{\circ}{ }^{\wedge}$ Constitucional, Lisboa, Imprensa Nacional - Casa da Moeda, 1983, p. 55. 


\section{Revoltas e Revoluções}

mento na guerra de África, na descolonização e no processo revolucionário desencadeado a 25 de Abril de 74 .

Ora só os partidos políticos se apresentavam com capacidade de gerir a diversidade dos interesses desencadeados, servindo ao mesmo tempo de andaimes na construção dos factores de coesão da comunidade portuguesa nessa sua nova fase. Os interesses em jogo eram tão contraditórios que só os partidos poderiam geri-los por difíceis que fossem, no quadro das liberdades públicas instauradas. Daí o fracasso de todas as organizações que se quiseram arrojar o exclusivismo da condução do processo no período revolucionário.

Interesses contraditórios geridos por instrumentos separadores (os partidos) mas dentro de um sistema de decisão fortemente concentrado. Daí a facilidade com que os militares aceitaram e impuseram uma lei tão violenta como a lei da unicidade sindical ou a lei sobre os partidos que atribuiu a estes o monopólio do acesso à actividade política.

A estratégia militar passou ainda pela co-responsabilidade das pressentidas maiores correntes partidárias que entraram nos Governos provisórios onde se aprisionaram os partidos a troco da sua implantação na quadrícula do país, favorecendo a referida necessidade de centralização das decisões tomadas revolucionariamente e a sua execução (descolonização, nacionalizações, reforma agrária, autonomias insulares, etc.).

Os partidos acabaram por se revelar os instrumentos mais apropriados à condução do processo político em Portugal e tornaram-se, com os primeiros governos provisórios, as maiores criações institucionais da Revolução.

Um dos factores de fortalecimento do papel dos partidos políticos foi a operação de recenseamento desencadeada em Dezembro de 1974 e que elevaria o corpo eleitoral português em mais quatro milhões de votantes. Acresce que a participação eleitoral revelou-se fortíssima no sufrágio para a Constituinte.

As próprias eleições para a Assembleia Constituinte em Abril de 1975 foram fundamentais para o estabelecimento em Portugal do sistema pluripartidário, e a garantia dada pelo M.F.A. de que essas eleições se realizariam constitui prova da existência de uma estratégia militar para se alcançar o objectivo de dotar o país de um regime democrático. Nesse particular é indesmentível a influência do general Costa Gomes que faz aprovar uma moção nesse sentido no fim da Assembleia do M.F.A. realizada de 11 para 12 de Março de 1975.

A confirmação desse empenhamento do M.F.A., e de Costa Gomes, na realização de eleições para a Assembleia Constituinte, encontra-se no testemunho de um dos mais activos em- 
baixadores em Lisboa na altura, o embaixador belga, que nos relata uma entrevista que lhe foi dada pelo P. R.:

«Je fus reçu dans l'après-midi du Vendredi Saint. L'audience dura près d'une heure. Le General Costa Gomes que j'avais rencontré à plusieures reprises déjà, m'écouta attentivement. Lui, généralement peu loquace me répondit longuement. Il comprenait l'inquiétude du Gouvernement Belge, comme celle des autres gouvernements. Il tint à me rassurer sur les prochaines élections libres et au suffrage universel, gage du MFA à l'objectif fixé» $\left.{ }^{8}\right)$.

É certo que no domínio institucional muitos foram os conflitos entre o M.F.A. e os partidos políticos, em termos de concepção do tipo de regime a estabelecer em Portugal, e essa própria concepção esteve à mercê de uma certa relação de forças exteriores ao M.F.A. ; por exemplo um triunfo eleitoral do P.C.P. e do M.D.P./C.D.E., teria dado origem a um regime político de características muito diferenciadas do modelo predominante na Europa Ocidental.

Assim a vitória eleitoral do Partido Socialista nas eleições para a Constituinte veio a determinar o estabelecimento de um regime de democracia pluralista, ainda que posto em causa até ao 25 de Novembro. A partir dessa data ficou claro que só um pacto entre os partidos políticos e as Forças Armadas poderia resolver institucionalmente a questão política portuguesa.

Esse trânsito efectuado pelas F. A. portuguesas entre o regime de ditadura derrubado a 25 de Abril de 74 e a promulgação da Constituição a 25 de Abril de 76 é notável e sem exemplo na história das intervenções militares em Portugal.

Esse trânsito constituiu a escolha de um autêntico «objectivo nacional de alternativa», para utilizar um conceito ministrado nos institutos superiores militares sobre o «poder nacional» no mundo.

Ora uma das características da condução do processo político desencadeado pelo M.F.A. será a revelação de uma elite militar com capacidade de pensamento estratégico sobre a instituição militar e sobre a resolução de grandes problemas nacionais. E essa elite, de uma forma geral, manter-se-á de acordo para considerar o regime democrático pluralista como o mais adequado à afirmação do Estado Português e à sobrevivência da própria instituição militar.

$\left.{ }^{8}\right) \quad$ Embaixador Max Very, Le Rétablissement de la Démocratie au Portugal, Policopiado, p. 180. 


\section{Revoltas e Revoluções}

A existência dessa elite militar intelectual não é geralmente reconhecida extra-muros, por parte de outras elites nacionais, desde a universitária à empresarial, desde a dos grandes «corpos de Estado» aos tecnocratas. E, no entanto, essa elite existe e teve papel preponderante no trânsito entre o período revolucionário e o estabelecimento de um regime democrático-constitucional.

Essa elite militar tem origem e curriculum diversos, desde o oficial com o Curso de Estado-Maior até ao militar com particular experiência de comando.

Treinada nos «Estudos de Situação Estratégica» dos estabelecimentos de Ensino Militar Superior, parte dessa elite maneja com grande operacionalidade as aquisições das ciências sociais e de estratégia. Os factores de «coesão social» ou o inventário das vulnerabilidades ou potencialidades nacionais são o protótipo de uma mentalidade desconhecida fora do território castrense. Outra parte dessa elite tem particular experiência de organização e comando e um conhecimento empírico do real.

Essa elite "salvou» a instituição militar no meio de todas as crises nacionais recentes, nomeadamente as relacionadas com a guerra colonial, a descolonização, o processo revolucionário e a cristalização do regime democrático de partidos.

E quando se afirma que as Forças Armadas foram «salvas» isso significa que elas se mantiveram como instituição idênticas a si mesmas.

Nessa perspectiva o M.F.A. foi uma metamorfose da instituição militar, e o II Pacto M.F.A.-Partidos de Fevereiro de 1976 corresponde ao essencial da estratégia militar no campo político após o derrube da ditadura.

Porém, a revolução do 25 de Abril não influenciou apenas o poder político. Ela provocou consequências variadas nos domínios social e económico. II.

\section{ASPECTOS SOCIAIS E ECONÓMICOS DA REVOLUÇÃO}

A essência de todo este ensaio sobre a revolução portuguesa desencadeada a 25 de Abril de 74 é mostrar a predominância dos fenómenos políticos e institucionais sobre outros factores explicativos dos sucessos ocorridos no período pré-constitucional.

Todavia, um ensaio histórico sobre este período ficaria incompleto - e seria ainda mais imperfeito - caso não relatasse os aspectos sociais e económicos tidos por mais relevantes ou singulares. Tratando-se de um ensaio histórico, esses aspectos sociais e económicos serão abordados dentro de uma disciplina 
cronológica, se bem que a partir de distinções sectoriais. Não se procure, pois, aqui, um estudo da situação económica e social daquele período, que só outras abordagens económicas ou sociológicas poderiam exprimir.

Aspectos sociais e económicos relevantes ou singulares, como é próprio de uma ciência que deles assim se ocupa.

Acresce que muitos dos aspectos económicos revelados pela revolução tiveram uma expressão social prévia, caracterizada pelo tipo de relações de trabalho estabelecidas dentro das empresas ou pelo modo de vida de vastas camadas da população, sobretudo nas cinturas industriais de Lisboa, Setúbal e Porto.

Estas características, formadas durante o regime anterior de autocracismo empresarial e de vida urbana degradada, iriam ser os suportes de uma movimentação social disputada na sua condução por dois vectores políticos, um de cariz classicamente bolchevista e outro de componente mais complexa tendente ao estabelecimento de formas de democracia directa, dentro de uma linha de «poder popular», cuja carta constitucional seria o Documento-Guia Povo-M.F.A. de Julho de 1975.

Já na teoria das nacionalizações que marcarão os aspectos económicos da revolução é visível o interesse de outra estrutura do M.F.A., o Conselho da Revolução, assim como a larga coincidência com o plano de nacionalizações aprovado pelo P.C.P. desde 1965.

Comecemos pelos aspectos sociais desencadeados pela revolução do 25 de Abril.

\section{Os aspectos sociais da Revolução}

Tudo começou pela ocupação de casas vazias no Bairro Social de Cheias.

No dia 8 de Maio de 1974 opera-se uma manifestação de ocupantes do Bairro Social de Cheias junto ao Palácio de Belém para conseguirem a legalização daquela situação de facto. Terão os manifestantes alcançado os seus intentos pois que a 11 de Maio um comunicado da J.S.N. informa que esta não permitiria que se realizassem mais ocupações abusivas de casas $\left({ }^{9}\right)$.

O certo é que nas duas semanas seguintes cerca de duas mil casas são ocupadas em todo o país e já a 11 de Maio ter-se-ia eleito a primeira «comissão de moradores», num dos

(8) Diário Popular, de 11 de Maio de 1974. 
bairros de lata de Lisboa, com a participação de duzentas e trinta famílias $\left({ }^{10}\right)$.

A partir daí uma relação fica estabelecida entre o problema habitacional e a existência de comissões de moradores.

Segundo Charles Downs, podem distinguir-se quatro fases na vida das «comissões de moradores»: a primeira de Abril até Novembro de 74; a segunda de Novembro de 74 a Março de 75; a terceira de Março de 75 a Novembro de 75; e a quarta de Novembro de 75 em diante.

Assim, nos primeiros meses depois de Abril, observa-se a formação de «comissões de moradores», sobretudo nos bairros de lata em Lisboa e nos bairros camarários no Porto.

A segunda fase é marcada pelos efeitos das campanhas de dinamização cultural e dos apelos nelas lançados para que as populações se organizassem na resolução dos seus próprios problemas. Será na região de Setúbal que esses apelos terão maior eco.

Durante o ano de 75 assiste-se a uma multiplicação de órgãos de poder popular com o aparecimento de «comités de ocupantes» que bastas vezes se opõem às «comissões de moradores», próximas das administrativas juntas de freguesia, de influência M.D.P./C.D.E. e P.C.P.. Essas «comissões de moradores» começaram a condenar certas ocupações de casas, consideradas selvagens ou oportunistas. Estamos mais uma vez perante a luta institucional entre o P.C.P. e certas organizações de.extrema esquerda, nomeadamente a U.D.P., fortalecidas pela influência militar de Otelo que contava assim captar as populações para a estratégia do M.F.A.

Em Abril de 1975, existem em Lisboa trinta e oito comités de ocupantes, vinte e uma comissões de moradores e cinquenta e quatro juntas de freguesia em funcionamento $\mathrm{O}^{1}$ ).

Entretanto criam-se mais «comissões de moradores» com vista à ligação, preconizada pelo Documento-Guia do M.F.A. em Julho de 75, entre «comissões de moradores» e «comissões de trabalhadores» para a edificação do «poder popular». No fim deste período, em Novembro de 75, contam-se, na cidade de Setúbal, cerca de trinta «comissões de moradores» cobrindo perto de dois terços da população $\left({ }^{12}\right)$.

(10) Ver Charles Downs, «Comissões de Moradores» and Urban Struggles in Revolutionary Portugal - comunicação policopiada apresentada no II International Conference Group on Modern Portugal, Universidade de New Hampshire, Junho de 1979, p. 5.

(u) Charles Downs, ob. citp. 9.

(12) Charles Downs, ob ${ }_{\dot{e}}$ cit., p. 9. 
Enquanto que a primeira vaga de ocupação de casas se dirigiu principalmente para os chamados «bairros sociais» - tendo o Governo sido pressionado pelos acontecimentos a legislar a favor dos inquilinos através do decreto-lei n. ${ }^{\circ} 445 / 74$ de 12 de Setembro - já a vaga iniciada com as ocupações na noite de 18 de Fevereiro de 75 se orienta para casas particulares. Existe uma estimativa feita que indica terem sido ocupados, nos dias seguintes a 18 de Fevereiro de 75, cerca de dois mil e quinhentos apartamentos. $(1 \mathrm{~S})$.

Estas últimas ocupações já demonstram um certo grau de organização e de resistência à intervenção policial. Intervenção policial que permite contudo um interregno de mais de um mês na vaga de ocupações, que só serão retomadas em Abril.

As ocupações de Abril de 75 também se orientam para casas particulares mas os seus promotores acrescentam agora uma dimensão de urbanização integrada, com a organização de equipamentos colectivos - como creches, centros clínicos e parques infantis, a maior parte de duração efémera.

A ocupação de casas e a organização de «comissões de moradores» torna-se cada vez mais uma actividade planificada e organizada por grupos políticos radicais ou radicalizados. Já não são só os habitantes dos bairros da lata ou de prédios degradados que passam a estar presentes nessas manifestações. A chegada de retornados ou refugiados de África veio introduzir uma outra dimensão na escassez da oferta de habitação e muitos desses retornados serão elementos activos dessas ocupações.

O fenómeno alastrava. À insegurança dos proprietários e dos senhorios juntou-se a insegurança manifestada pelos emigrantes quanto às casas que mandavam construir em Portugal com particular empenho. De tal maneira que um dos problemas prévios à formação do VI Governo Provisório foi a inclusão no Programa deste de um plano de desocupação dos prédios ilegalmente ocupados.

Não deixa no entanto de ser importante assinalar-se que os próprios ocupantes de casas e as "comissões de moradores» que os representavam oscilaram sempre entre um anarquismo espontaneista e um comportamento de compromisso com as estruturas do Estado procurando a legalização formal dos seus actos à luz do direito vigente.

Vejamos agora, para se ilustrar a via que liga os movimentos sociais e reivindicativos à formação do poder popular,

(13) Estudantes do Instituto Superior do Serviço Social, Um Contributo para a Análise do Processo de Ocupações em Lisboa e Arredores, citado por Charles Downs, ob. cit., p. 17. 


\section{Revoltas e Revoluções}

como se vai tecendo, nos locais de trabalho, o paralelo movimento basista consubstanciado, nas empresas, no aparecimento de «comissões de trabalhadores» e a expressão final de alguns desses casos nas experiências autogestionárias.

Está fora de dúvida que o objectivo do M.F.A., ao desencadear o golpe militar, era o de promover imediatamente a existência de um poder político concentrado que tivesse autoridade e instrumentos para efectuar o trânsito até ao período constitucional com a máxima segurança. Ainda se pode imaginar que a vaga de ocupações de casas ocorrida e retratada atrás pudesse oferecer algumas virtualidades para o enlace que o M.F.A. queria promover entre si e a população «mais desprotegida», enlace com o qual queria conquistar um apoio popular necessário para se fortalecer na condução do processo político. O mesmo não se pode admitir para a proliferação de conflitos nas empresas que passaram a desenrolar-se sem qualquer limite, com riscos permanentes de derrapagem económica, social e política e que aparentemente nenhum grupo conseguia controlar.

Ora o próprio P.C.P. inicia as suas relações com a J.S.N. - e a sua participação no I Governo Provisório - com grandes cautelas e com um grande sentido de colaboração na transição para um regime democrático sem grandes convulsões internas.

Uma equipa de sociólogos chega a caracterizar esse período inicial nos seguintes termos:

«O horizonte temporal vai desde 25 de Abril até 31 de Maio de 74 , período particularmente rico e significativo do movimento social explosivo que se seguiu à queda da ditadura. É curioso assinalar que o dia 1 de Junho marca uma manifestação - que teremos de considerar original 'contra a greve pela greve', organizada pela Intersindical, com o apoio do Partido Comunista a qual terminou junto do Ministério do Trabalho» $\left({ }^{14}\right)$.

Aquela mesma equipa recenseou os conflitos empresariais ocorridos durante esse período e estabeleceu a seguinte classificação:

Um primeiro grupo, de cerca de noventa casos, em empresas industriais abrangendo as actividades «extractivas, vidros e cimentos», «químicas e petróleo», «metalúrgicas e metalo-mecânicas», «material eléctrico e de transporte», «construção e obras públicas».

(14)Maria de Lourdes Lima Santos, Marinus Pires de Lima, Vitor Matias Ferreira, $O 25$ de Abril e as lutas sociais nas Empresas, Porto, ed. Afrontamento, 1976, vol. I, p. 34. 
Um segundo grupo em que ocorreram perto de sessenta conflitos, englobando «electricidade, gaz e água», "comércio», «transportes e comunicações».

Um terceiro grupo, «nos serviços, banca e seguros», com uma dezena de casos.

Quanto às formas de luta, elas foram desde as manifestações de rua até ao sequestro de pessoas e bens passando pela ameaça de greve, declarações de greve parcial, de greve total e da própria ocupação das empresas.

As ocupações e sequestros de pessoas e bens, sendo as mais originais e violentas no processo português, merecem outro desenvolvimento.

No que diz respeito às ocupações, e em relação ao total dos casos referenciados para o período de 25 de Abril a 1 de Junho de 74 , esta forma de luta atinge mais de $20 \%$ do total, sendo este de 35. Para a quase totalidade das ocupacões, estas estão associadas à greve total. O significado político das ocupacões não deixa de ser o de uma autêntica subversão das estruturas do poder dentro da empresa, embora as causas que desencadearam essas ocupações pudessem ter sido variáveis (quebra no pagamento dos salários, retirada de material pelos donos das empresas, tentativas de despedimentos, etc.). O sequestro de pessoas e bens iria repetir-se ao longo do período pré-constitucional mas começou com os casos das empresas Safil, Lisnave e Luso-Belga (15).

A rejeição, pelas entidades políticas, destas formas de luta, que já vimos também não interessarem a qualquer estratégia do M.F.A., intensifica-se depois da formação do I Governo Provisório. Assim, a 29 e 31 de Maio, Spínola condena esses actos em discursos proferidos em Coimbra e no Porto; também a 29 de Maio, o Governo Provisório condena os grupos que põem em perigo a estabilidade do país; o P.S. ataca as greves indiscriminadas como já havia feito o P.C.P. no seu comício em Lisboa a 24 de Maio através de Carlos Brito; na noite de 29 de Maio realiza-se uma mesa-redonda na televisão em que se pede moderação no uso da greve e onde estarão presentes Melo Antunes e representantes do P.P.D., P.S., M.D.P., P.C.P. e Intersindical.

Neste processo de lutas sociais que temos vindo a descrever pode-se observar dois períodos bem distintos. $\mathrm{O}$ primeiro é o período de Maio a Junho de 74 já analisado, e o segundo dá-se entre Janeiro e Março de 75. Em que consistiu essa dife-

(15) Lima Santos, et. al., ob. cit., pp. 39-40. 


\title{
Revoltas e Revoluções
}

rença? Essencialmente na mudança de conteúdos das reivindicações mais importantes e nas respectivas formas de luta.

Assim, no período de Maio a Junho, as exigências são sobretudo de carácter salarial, recorrendo-se à ameaça de greve ou à greve parcial e também total; no período entre Janeiro e Março de 75, acentua-se a reivindicação dos saneamentos das hierarquias superiores das empresas, sendo a forma de luta mais utilizada a ocupação das empresas.

Os sucessos que assinalam a transição entre os dois períodos são a manifestação da Lisnave a 12 de Setembro de 74, em que se reclama o saneamento das empresas e a manifestação contra os despedimentos em Fevereiro de 1975.

Como diz expressamente a obra de referência que seguimos:

\begin{abstract}
«Um outro elemento parece significativo na demarcação entre esses dois momentos reivindicativos: referimo-nos às estruturas organizativas mobilizadoras dessas movimentações sociais. Se, manifestamente, o período reivindicativo de Maio/Junho de 74 é fort emente dinamizado por Comissões de Trabalhadores, muitas vezes eleitas expressamente para conduzirem determinados conflitos, passando posteriormente, a uma fase de relativa institucionalização, verificamos que, pelo contrário, no momento seguinte'(Janeiro/Março de 75), o movimento reivindicativo é, muitas vezes, 'conduzido' e 'enquadrado' com articulações mais ou menos directas a certos aparelhos partidários» ( ${ }^{(\mathrm{fl})}$.
\end{abstract}

É indiscutível ser do Partido Comunista e da Intersindical que se quer falar neste remate. E de facto, como analisar essa diferença de comportamento do Partido Comunista perante as lutas sociais entre Maio e Junho de 74 e Janeiro-Março de 75 ? Esta é uma questão central para se compreender o comportamento do Partido Comunista depois do 25 de Abril, e se de facto houve uma planificação táctica das suas posições.

O que não oferece dúvidas é ter havido uma grande prudência no período inicial da revolução, para se passar para um apoio declarado às grandes movimentações populares entre Janeiro e Março de 75 que antecederam o «saneamento» de muitas empresas e as próprias nacionalizações efectuadas depois do 11 de Março.

É bem possível que a grande manifestação organizada por este partido e pela Intersindical a 14 de Janeiro de 1975 tenha surpreendido e entusiasmado os responsáveis pela linha política do Partido Comunista. De facto, essa manifestação, con-

(Ifl) Lima Santos et. al., ob. cit., p. 58. 
vocada para apoiar o Ministro do Trabalho na sua posição favorável à unicidade sindical, revelou uma capacidade de mobilização e de organização notáveis, se bem que sem falha de recursos materiais.

A partir daquela manifestação e de ter alcançado a hegemonia sindical, o P.C.P. irá alimentar e apoiar inúmeros conflitos nas empresas, tendentes a um vasto movimento de saneamento de empresários e gestores e à execução do plano de nacionalizações previsto para a fase da «revolução democrática e nacional». É possível que uma certa emulação com forças de extrema esquerda, nomeadamente a U.D.P., tenha obrigado o P.C.P. a uma radicalização menos racional e a misturar-se em conflitos que, em princípio, não se apresentavam com probabilidades de sucesso. O certo é que, perante os problemas económicos que se anunciam para o país, adopta, a partir de Junho de 75 , a política da «batalha da produção», que iria ser acompanhada pela criação de órgãos de poder comunista dentro das empresas, os chamados «comités de defesa da revolução».

O enquadramento do P.C.P. não é porém total. Basta atender à generalização das experiências autogestionárias, sempre condenadas por aquele partido. Será antes o Partido Socialista e determinados grupos de extrema esquerda que irão tentar dar corpo político a uma série de casos de transferência do poder de decisão e gestão nas empresas, dentro de fórmulas encontradas na família autogestionária.

Um despacho do Secretário de Estado do Trabalho de 24 de Fevereiro de 76, (publicado no Diário do Governo em 5 de Março de 1976) informa existirem naquela data duzentas e vinte e uma empresas «credenciadas». Como se chegou aí?

Segundo F. Marcelo Curto $\left({ }^{17}\right)$ as Comissões de Trabalhadores já existiam em Portugal antes do 25 de Abril. Essas comissões tomaram diversas formas e exerceram várias funções, chegando a ser reconhecidas como Comissões Internas em certos Acordos Colectivos de Trabalho, como por exemplo nas empresas CEL-CAT, CUF, EFACEC ou CPE. Constituiram-se também Comissões de Higiene e Segurança, e outras chamadas Espontâneas, estas não legalizadas, as quais promoveram acções reivindicativas à margem dos sindicatos corporativos, como aconteceu na SOREFAME nos inícios de 1974. Afirma Marcelo Curto a este respeito:

«As primeiras (Comissões de Higiene e Segurança) eram órgãos tolerados pelas empresas, desempenhando funções limitadas de defesa de aspectos que interessavam

$\left({ }^{17}\right)$ tágono, 1980 .

Marcelo Curto, Democracia na Empresa, Lisboa, Ed. Hep- 


\section{Revoltas e Revoluções}

os trabalhadores (higiene e segurança), mas que interessavam e interessam à própria empresa e ao patronato. Por vezes, as comissões tentavam negociar com a direcção da empresa esquemas de participação consultiva, aparentados com experiências estrangeiras, como foi o caso da TAP e da CPE já no ano de 1973» (18).

Depois do 25 de Abril toda essa variedade de comissões passaram a actuar à luz do dia e enveredaram pela via reivindicativa em coordenação ou não com os sindicatos, e sempre ao nível da empresa. O que leva Marcelo Curto a afirmar:

«Não é possível, ou, pelo menos, não é sério explicar a vitalidade das Comissões de Trabalhadores depois do 25 de Abril por um fenómeno de espontaneidade da classe trabalhadora de tipo populista, determinado pela influência e acção de grupos esquerdistas radicais. As acções dos trabalhadores da LISNAVE, dos CTT, da TIMEX, por exemplo, na sua capacidade organizativa e na pertinácia dessas lutas, revelam toda a experiência e significado das acções levadas a cabo pelos trabalhadores dessas empresas antes do 25 de Abril» (19).

Segundo um inquérito do Ministério do Trabalho realizado em Dezembro de 1978, constata-se que, entre Outubro de 1974 e Fevereiro de 75, encontravam-se quinze empresas em autogestão; entre Março e Novembro de 75 entraram mais oitenta e oito; e durante o ano de 1976 outras vinte e oito $\left({ }^{20}\right)$.

Comum a outras experiências europeias de autogestão está o facto de muitas dessas empresas estarem anteriormente em situação económica difícil. Fenómeno particular do caso português foi a passagem de «credenciais» por autoridades políticas e administrativas do Estado.

A «credencial», segundo o despacho já referido de 24 de Fevereiro de 76, permitia a «prática de actos de gestão considerados indispensáveis à sobrevivência da empresa», assim como «actos de gerência ordinária da empresa, incluindo a movimentação da conta bancária» ficando no entanto excluídos os poderes de disposição do capital fixo da empresa.

Numa primeira fase, diversas foram as autoridades militares e civis que emitiram credenciais. Porém, independentemente dessa diversa origem, as credenciais tinham em comum

(18) Marcelo Curto, ob. cit., p. 131.

(19) Marcelo Curto, ob. cit., p. 137.

(") Ver «Relatório da Comissão Inter-Ministerial para Análise da Problemática das Empresas em Auto-Gestão», criada por despacho publicado no Diário da República, III série, 5 de Março de 1979, pp. 49 a 181. 
$o$ serem actos administrativos conferindo às comissões de trabalhadores poderes mais ou menos amplos para representarem as respectivas entidades proprietárias das empresas.

O fenómeno da autogestão, completamente desconhecido em Portugal antes do 25 de Abril e jamais tendo a simpatia do Partido Comunista, chegou a atingir largas centenas de empresas. Já apresentámos um número exacto de empresas credenciadas (duzentas e vinte e uma), mas várias estimativas sobre o número de empresas em autogestão sem reconhecimento do Estado atiram para cerca de um milhar de unidades nessa modalidade de gestão durante o período pré-constitucional. O relatório que seguimos apresenta-nos o número de novecentos e trinta e sete empresas, nessas condições, desde a primeira experiência, iniciada a 17 de Maio de 1974, na Empresa de Publicidade do Algarve em Tavira até aos nossos dias (21).

Por Ministérios da tutela essas empresas foram assim distribuídas:

$\begin{array}{lr}\text { Min. da Indústria } & 772 \\ \text { Min. do Comércio e Turismo } & 130 \\ \text { Min. da Habitação e Obras Públicas } & \mathbf{1 0} \\ \text { Min. dos Transportes e Comunicações } & 8 \\ \text { Min. da Educação e Cultura } & 4 \\ \text { Min. da Agricultura e Pescas } & 9 \\ \text { Min. dos Assuntos Sociais } & 3 \\ \text { Min. da Comunicação Social } & \mathbf{1}\end{array}$

O volume mais significativo de empresas em autogestão situa-se, pois, no sector secundário. Essas empresas estão concentradas sobretudo no distrito de Lisboa (299), Porto (174), Setúbal (63), Braga (39), Aveiro (27) e Santarém (26). Por actividades, essas empresas apresentam a seguinte distribuição: metalo-mecânicas (222), têxteis (172), gráficas (10), alimentares (55) e mobiliárias (35) (22).

Já as 130 empresas sob tutela do Ministério do Comércio estão concentradas em Lisboa (71), Porto (19), Funchal (10) e Faro (8). Por sectores, 90 pertencem ao Comércio e 40 ao Turismo (23).

Muitas dessas empresas encontravam-se em autogestão «selvagem» - ou seja, sem «credencial» passada por qualquer autoridade competente do Estado - e portanto o seu número é aproximado. Com o fim de regularizar o maior número pos- ${ }^{*}\left(^{*}\right)$

(21) Ob. cit., pp. 49 e 179.

(“) Ob. cit., p. 182.

(*) Ob. cit., p. 182. 
sível de empresas em autogestão foi publicado a 15 de Março de 1976, durante a vigência do VI Governo Provisório, um despacho no Boletim do Ministério do Trabalho ao abrigo do qual foram emitidas mais 283 credenciais $\left({ }^{24}\right)$.

Muitos outros aspectos da movimentação social poderiam ter sido estudados e aqui apresentados, todavia estes têm o mérito de terem sido dos mais característicos e originais no período pré-constitucional, assinalando também uma grande dificuldade no exercício do controlo político sobre o domínio da movimentação social desencadeada pelo colapso do regime autoritário e corporativo derrubado a 25 de Abril.

Em suma, enquanto a estratégia militar conseguiu introduzir alguma racionalidade na formação do poder político de transição, de tal já não foi capaz para enquadrar a movimentação social, talvez demasiado espontaneísta e irregular para ser previsível. Otelo Saraiva de Carvalho tentou fazer a ligação entre a movimentação social e o Movimento das Forças Armadas, primeiro empiricamente, sem desposar qualquer ideologia, como era próprio da estratégia militar, e depois, pela adopção de fórmulas ideológicas e políticas cada vez mais rígidas dentro de uma via de democracia directa conducente ao chamado «poder popular». Tal atitude também poderá ter sido uma forma de combate à influência do Partido Comunista na organização das populações. O P.C.P. conseguirá, no entanto, a hegemonia institucional, senão organizacional, através da legalização da Intersindical, dos comités de defesa da revolução, da influência em muitas comissões de moradores, e do domínio administrativo nas juntas de freguesia dos grandes centros industriais.

Mas essa hegemonia do P.C.P. irá encontrar um terreno mais favorável para se exercer quando o processo das nacionalizações for desencadeado.

\section{Aspectos económicos da Revolução}

Um dos elementos menos estudados tem sido o da natureza das nacionalizações efectuadas entre 1974 e 1976, e as suas implicações para o estabelecimento de um modelo económico viável de modernização da sociedade portuguesa.

As nacionalizações efectuadas foram de natureza política circunstancial se bem que acabassem por corresponder, nas suas linhas gerais, às medidas preconizadas pelo Partido Comunista ${ }^{(*)}$

(*) Ob. cit.j pp. 52-53. 
Português, para a sua fase de luta pelo poder denominada «Revolução Democrática e Nacional».

Foi Álvaro Cunhal quem, na sua obra Rumo à Vitória, elaborada em 64, definiu primeiro as tarefas do Partido Comunista na Revolução Democrática e Nacional. Depois, essas medidas foram aprovadas e integradas no Programa do P.C.P. durante o VI Congresso realizado em 1965.

Entre 1974 e 1975 ocorreram dois fenómenos tidos por paralelos mas passíveis de algumas correlações. Foram eles a rapidez do processo de descolonização, desde que desencadeado, e a facilidade política na tomada de decisões concernentes às nacionalizações.

Assente a descolonização uniforme, que o mito do «Portugal uno» facilitou, e sem que as negociações pudessem ter sido já acompanhadas pelos instrumentos adequados à fiscalização das decisões e compromissos, o Estado português teria que intervir decididamente nas consequências económicas da descolonização. Assim as relações imediatas com os novos países africanos só se poderiam articular racionalmente sem a pressão e a dispersão das influências e dos interesses particulares. Para isso ser possível, teve o Estado português que deter e que defender os interesses económicos e financeiros mais relevantes no chamado contencioso colonial.

Por outro lado, e utilizando conceitos simples de luta de classes, pode-se descobrir que a atenuação, ou mesmo eliminação, do domínio económico e político por parte dos grandes banqueiros nacionais, correspondia não só a uma exigência dos politizados sindicatos dos trabalhadores, mas contava com a expectativa benevolente de numerosos industriais e empresários tutelados nas suas actividades pelo capital financeiro.

A eliminação da hegemonia da burguesia financeira foi assim facilitada por factores ligados à descolonização, às relações entre as classes produtivas em Portugal, como ao próprio processo de subalternização do poder económico pelo poder político revolucionário, tendo neste último aspecto cabido um grande papel ao Partido Comunista.

A luta travada entre os empresários e o operariado pela repartição da riqueza produzida não impediu todavia, embora tivesse obscurecido a inteligência da situação, que os empresários e os trabalhadores apelassem até conjuntamente para a intervenção estatal no sistema de crédito. Posto que as classes trabalhadoras eram então politicamente mais fortes, a burguesia industrial e comercial viu-se suplantada na condução de um processo que, acaso de uma forma mais moderada, também lhe dizia respeito. A operação «política de crédito estatizado» foi objectivamente um ponto de convergência entre diversos grupos 


\section{Revoltas e Revoluções}

sociais submetidos à férrea disciplina financeira-corporativa e asfixiadas pelo «condicionalismo industrial». Essa convergência foi muito auxiliada por uma dinâmica de capilaridade por parte de uma categoria de gestores que se foram apropriando das decisões económicas fundamentais nas empresas em que trabalhavam. Todavia, enquanto que, para os grupos políticos que se reclamavam defensores dos interesses das classes trabalhadoras e dos gestores, a apropriação total dos meios de crédito e do sistema financeiro era tida por factor positivo, já os empresários teriam natural tendência para preconizarem um sistema bancário onde coexistissem a banca privada e organismos financeiros estatais. Só desse modo ficaria assegurada a sua autonomia de decisão, tanto em relação às entidades financeiras privadas, como em relação a orientações económicas demasiado imperativas do Estado.

Ora os estrategas das Forças Armadas apoiaram as nacionalizações mais por razões políticas do que por razões decorrentes da prossecução de um modelo económico colectivista.

É facto que vários modelos de modernização económica para o país se debatiam e que os responsáveis pela estratégia militar hesitaram em adoptar qualquer um. Só na conferência de imprensa dada a 31 de Dezembro de 1974, Franco Charais, da Coordenadora do M.F.A., afirmou que, se os meios económicos não colaborassem com a revolução, esta passaria de socializante a socialista.

O facto é que, de todas essas nacionalizações, não iria decorrer sequer um mero plano a médio prazo ou de reformas sectoriais, nomeadamente na indústria. $\mathrm{O}$ que leva a concluir-se historicamente pela tese de uma alta percentagem de empirismo e circunstancialismo nas decisões económicas tomadas durante o período pré-constitucional.

Mesmo assim podemos detectar alguns fios condutores.

As primeiras nacionalizações ocorrem ainda com Spínola na Presidência da República e dizem respeito aos bancos emissores. Assim, os decretos-leis n. ${ }^{\circ} 450,451,452 / 74$, todos de 13 de Setembro e publicados no Diário do Governo n. ${ }^{\circ} 214$, nacionalizaram o Banco de Angola, o Banco Nacional Ultramarino e o Banco de Portugal respectivamente. É o primeiro passo para o Estado ocupar o único lugar do lado português na gestão das consequências financeiras da descolonização que se desencadeara oficialmente com a lei $\mathrm{n} .^{\circ} 7 / 74$ de 26 de Julho. Nesse entendimento comungavam todas as entidades envolvidas na decisão de descolonizar.

Depois da demissão de Spínola, segue-se o decreto-lei n. ${ }^{\circ}$ 540-A/74 de 12 de Outubro, em que se determina a intervenção do Estado na superintendência, coordenação e fiscali- 
zação de actividades das instituições de crédito e das instituições para-bancárias.

Dentro da mesma tendência para estabelecer a intervenção do Estado na vida económica através do controlo financeiro, o decreto-lei n. ${ }^{\circ}$ 671/74, publicado a 21 de Novembro, confere ao Ministro das Finanças a faculdade de determinar ao Banco de Portugal a designação dos delegados deste junto das instituições de crédito, reforçando assim a capacidade de coordenação do Banco Central.

Ao mesmo tempo, o poder político favorecia a organização dos interesses industriais, abolindo o «condicionamento industrial» de feição malthusiana e corporativista através do decreto-lei n. ${ }^{\circ}$ 583/74, publicado a 10 de Outubro, e promulgando o decreto-lei n. ${ }^{\circ}$ 695/74 a 5 de Dezembro, conferindo às entidades patronais $\mathrm{o}$ direito de se constituirem em associações para a defesa e promoção dos seus interesses. Em conformidade, Vasco de Melo, que presidiria à CIP, afirmava em Londres, no mês de Dezembro de 74, ter havido mais greves durante a ditadura do que no período revolucionário que decorria.

O primeiro grande desvio sobre o modelo económico que se desenhava para o Portugal democrático foram as medidas avulsas tomadas nas vésperas do Congresso do Partido Socialista, em 12 de Dezembro de 74, e que introduziram a intervenção directa do Estado na gestão das empresas. De qualquer modo, ainda não se assistia a uma nova teoria sobre o papel do Estado na organização económica.

Tais acções (demissão dos corpos gerentes da Torralta e do B.I.P.) haviam sido previamente preparadas por um discreto decreto-lei, o $\mathrm{n} .{ }^{\circ}$ 660/74, da iniciativa da própria Presidência do Conselho de Ministros e publicado a 25 de Novembro. Esse decreto-lei fixava as normas sobre a assistência do Estado às empresas privadas, individuais ou colectivas, que não funcionassem em termos de contribuir «normalmente para o desenvolvimento económico do País». O decreto-lei n. ${ }^{\circ}$ 660/74 iria ser um instrumento privilegiado da intervenção do Estado na vida interna das empresas, sobretudo a partir de Abril de 75 e caracterizadamente pela demissão dos corpos gerentes de muitas empresas privadas e sua substituição por comissões administrativas nomeadas pelo Governo, algumas das quais sob resolução expressa do Conselho da Revolução nesse sentido.

A única estratégia entretanto prosseguida claramente continuava a dizer respeito ao sistema bancário, como se poderá verificar pela promulgação do decreto-lei $\mathrm{n} .^{\circ} 1 / 75$ de 2 de Janeiro que inseria disposições sobre o modo como os bancos de investimento financiariam as suas operações e sobre as condições em que se poderia operar a movimentação e o crédito 


\section{Revoltas e Revoluções}

das contas de depósito à ordem abertas nos mesmos bancos, e indicava as operações cambiais que o Banco de Fomento poderia realizar.

A questão do plano económico de emergência elaborado por essa altura por uma equipa dirigida por Melo Antunes e na qual figuravam, entre outros, Rui Vilar, Silva Lopes, Maria de Lourdes Pintasilgo e Vítor Constâncio, coloca ao historiador uma opção metodológica de fundo, a qual é a de se saber qual o lugar, dentro da hierarquia dos sucessos revolucionários, a atribuir aos meros planos e documentos que não foram executados e postos em prática. Estão no mesmo caso do Plano Económico de Emergência, o I Pacto M.F.A.-Partidos de Abril de 75, o Plano de Acção Política do M.F.A. de Junho de 75, o Documento-Guia Povo-M.F.A. de Julho de 75, assim como inúmeros textos produzidos em assembleias, do M.F.A. ou de forças políticas variadas e que não passaram de manifestos de intenção. A nossa tendência epistemológica é não considerar como acontecimento histórico algo que não passou de intenção sem qualquer execução prática.

Está nessa tipologia o Plano Económico de Melo Antunes elaborado no fim do ano de 74 e aprovado no Conselho de Ministros a 21 de Fevereiro de 75, para ser logo enfraquecido quer pelas críticas que sempre contra ele se elevaram nas assembleias do M.F.A. - e que encontraram eco, como iremos ver, no próprio Boletim do M.F.A. - quer essencialmente pela alteração das relações de forças no processo revolucionário português introduzida pelos acontecimentos decorrentes do 11 de Março de 75.

Premonitoriamente, o Boletim do M.F.A. n. ${ }^{\circ} 4$ de 12 de Novembro de 74 publicava um artigo intitulado «O M.F.A. - do político ao económico» em que se teciam abertas críticas ao Ministério da Economia e em que se alertava para as condições de êxito de um plano de acção económica para o qual o Conselho de Ministros incumbira, a 18 de Outubro, o Ministro militar do M.F.A. mais reputado no meio intelectual: o major Melo Antunes. Prevenia a linha de Vasco Gonçalves sobre as condições em que esse plano deveria ser elaborado:

«Julgamos que esse Plano deve assumir carácter de excepção, prever medidas de curto prazo (conjunturais) e lançar as bases para reformas indispensáveis ao nivel estrutural.... mas deve fazê-lo partindo do princípio de que à colectividade, através do Estado, deverá caber progressivamente um maior papel na actividade económica, quer pelo «controle» directo dos Departamentos, quer pela participação colectiva dos trabalhadores, verdadeiros criadores da riqueza nacional. Este aspecto assume especial relevo no sector agrícola onde continuam a existir formas 
de exploração ultrapassadas nas zonas de latifúndios e explorações com baixas rentabilidades onde a propriedade está muito dividida.

Supomos que as características, quer de elaboração, quer de execução e 'controle' deste Plano, exigem que ele se processe fora dos mecanismos burocráticos tradicionais dos Ministérios, e em especial do Ministério da Economia, devendo passar sobretudo pelo Primeiro-Ministro ou um Ministro sem pasta, servindo-se da estrutura do Secretariado Técnico hoje integrado na Secretaria de Estado do Planeamento Económico».

Este artigo é premonitório em relação à luta entre Vasco Gonçalves e Melo Antunes mas também indica o embate que se iria travar entre os diversos modelos de modernização económica propostos para a nova fase da sociedade portuguesa. Mas terá havido mesmo diversas políticas globais em confronto para o estabelecimento de modelos económicos?

Por um lado, temos provas, como a do artigo transcrito, que nos sugerem ter existido um plano de acção conducente à política de nacionalizações e à elaboração de um modelo económico semelhante ao defendido pelo Partido Comunista Português para a fase a que esse partido chamava de «revolução democrática e nacional».

Por outro lado temos elementos que apontam para um certo empirismo nas decisões respeitantes às nacionalizações. É o caso de um diálogo que nos é relatado pelo general Franco Charais, tido no edifício onde se realizavam as reuniões do M.F.A. na Calçada das Necessidades, e ocorrido antes de 11 de Março. Nessa altura, uma equipa de economistas debruçava-se, conjuntamente com a Coordenadora do M.F.A., sobre os diferentes modelos económicos considerados mais convenientes para a modernização da sociedade portuguesa. Sobre a política das nacionalizações, o eng. ${ }^{\circ}$ Veiga de Oliveira, destacado membro do P.C.P., pergunta:

— «Os Senhores têm força?»

E perante a resposta da Coordenadora do M.F.A. :

- «Bem, força temos alguma, mas não teremos toda...».

Veiga de Oliveira afirmaria:

— «Então não nacionalizem» $\left({ }^{25}\right)$.

Com o desenrolar dos acontecimentos consequentes ao 11 de Março, muda-se a relação de forças e, à institucionalização do Conselho da Revolução como órgão de soberania, seguem-se simultaneamente as nacionalizações da Banca e dos Seguros.

(25) Segundo entrevista oral dada ao autor deste trabalho. 


\section{Revoltas e Revoluções}

Mais uma vez encontramos contexto pertinente para pôr em realce os factores institucionais no estabelecimento quer do regime político quer do modelo económico na revolução portuguesa. As nacionalizações da banca e dos seguros são, assim, o modo de celebrar o nascimento do Conselho da Revolução como órgão de soberania e de lhe dar apoio popular, ao mesmo tempo que atribuíam ao Estado o poder financeiro. Esta atribuição ao Estado do poder financeiro permitir-lhe-á melhor gerir as consequências económicas da descolonização e imprimir-lhe maior capacidade de controlo da actividade económica.

Ressalta portanto desta evolução terem sido as nacionalizações da Banca e dos Seguros, ocorridas a 14 de Março de 75, ainda obra da estratégia militar. É o próprio general Costa Gomes quem anuncia e considera essas nacionalizações como a medida mais revolucionária do Portugal contemporâneo.

Aliás a filosofia económica subjacente a essa medida nem é originariamente marxista, antes entronca na doutrina de Saint Simon para quem o crédito, além de ser a «espiritualização do capitalismo», era sobretudo o grande meio de dirigir a economia e repartir a riqueza. Essa noção de direcção e controlo da economia através do crédito está bem expressa nos Preâmbulos dos decretos-leis n. ${ }^{\circ} 132-\mathrm{A} / 75$ de 14 de Março e n. ${ }^{\circ} 135-\mathrm{A} / 75$ de 15 de Março, ambos dimanados do recém formado Conselho da Revolução. Atente-se nalguns considerandos do decreto-lei n. ${ }^{\circ} 132-\mathrm{A} / 75$ publicado no Diário do Governo $1 .^{\mathrm{a}}$ série, n. ${ }^{\circ} 62$ de 14 de Março:

«Considerando a necessidade de concretizar uma política económica anti-monopolista que sirva as classes trabalhadoras e as camadas mais desfavorecidas da população portuguesa, no cumprimento do Programa do M.F.A.;

Considerando que o sistema bancário na sua função privada, se tem caracterizado como um dos elementos ao serviço dos grandes grupos monopolistas, em detrimento da mobilizaçã̃o da poupança e da canalização do investimento em direcção à satisfação das reais necessidades da população portuguesa e ao apoio às pequenas e médias empresas

Considerando que o sistema bancário constitui a alavanca fundamental de comando da economia, e que é por meio dele que se pode dinamizar a actividade económica, em especial a criação de novos postos de trabalho;

Considerando que os recentes acontecimentos de 11 de Março vieram pôr em evidência os perigos que para os superiores interesses da Revolução existem se não forem tomadas medidas imediatas no campo do controle efectivo do poder económico;

Considerando a necessidade de tais medidas terem em atenção a realidade nacional e a capacidade demonstrada pelos trabalhadores da banca na fiscalização e controle do respectivo sector de actividade; 


\begin{abstract}
Considerando, finalmente, a necessidade de salvaguardar os interesses legítimos dos depositantes;

(....)

Artigo $10^{\circ}-1$. São nacionalizadas todas as instituições de crédito» ( $\left.{ }^{\mathrm{TM}}\right)$.
\end{abstract}

O impacto destas nacionalizações foi enorme, quer do ponto de vista da psicologia colectiva, quer do ponto de vista das consequências geradas noutros sectores da vida económica do país.

Fixemo-nos agora na extensão das nacionalizações e noutras formas de intervenção do Estado na vida económica.

Foram diversos os órgãos de soberania e as modalidades legais que estenderam a intervenção do Estado na actividade das empresas, o que demonstra uma vontade política concertada de proceder a uma extensa colectivização dos meios de produção em Portugal. Assim, o Conselho da Revolução, evocando diversos artigos de diferentes Leis Constitucionais (sobretudo as leis $3 / 75$ e 5/75, ambas de 14 de Março), toma várias resoluções, quer recomendando ao Governo a demissão de corpos gerentes de certas empresas, quer arrogando-se ele próprio $\mathrm{o}$ direito de exonerar e nomear comissões administrativas. $\mathrm{O}$ primeiro caso está exemplificado na resolução do Conselho da Revolução de 21 de Março (27), em que este recomenda ao Governo a nomeação de uma comissão administrativa para a Sociedade Central de Cervejas. O segundo caso ilustra-se pela resolução que exonera e nomeia administradores do Banco de Portugal a 22 de Março.

O Governo, evocando o decreto-lei n. ${ }^{\circ}$ 660/74 de Novembro já referido, irá proceder a uma vasta operação de exoneração de corpos gerentes de empresas e de nomeação de comissões administrativas. Este processo será também usado em Março de 75 mas será sobretudo a partir de Maio e até Agosto daquele ano que a sua intensidade caracterizará a actividade dos Governos sob a presidência de Vasco Gonçalves.

O Governo procede também, a 16 de Abril de 75, a um vasto plano de nacionalizações dos sectores básicos da economia.

Deste modo, podemos observar dois grandes momentos, após as nacionalizações da Banca e dos Seguros decretadas pelo Conselho da Revolução: primeiro, uma série de nacionalizações efectuadas pelo Governo a 16 de Abril de 1975 - a meio da campanha eleitoral para a Constituinte - e uma segunda série

(“) Diário do Governo, n. ${ }^{\circ}$ 62, p. 394.

(27) Diário do Governo, 1. ${ }^{\mathrm{a}}$ série, $\mathrm{n} .^{\circ} \mathrm{68}, 4 .^{\circ}$ suplemento. 


\section{Révoltas e Revoluções}

depois das eleições e que abrandaria com o início dos trabalhos da Assembleia.

Nessa política de intervenção do Estado na vida económica, conduzida quer pelo Governo quer pelo Conselho da Revolução, é claro o empenhamento do Partido Comunista na exploração dos acontecimentos, aprofundando as medidas tomadas pelo Conselho da Revolução e procurando influenciar todos os centros de decisão capazes de elaborarem actos legislativos que cobrissem uma vasta operação de estatização da economia.

Será pelo decreto-lei n. ${ }^{\circ} 203-\mathrm{C} / 75$ de 15 de Abril que o IV Governo Provisório, através do Ministério para o Plano e Coordenação Económica, definirá o modelo económico que, em conformidade com o Conselho da Revolução, pretende para a sociedade portuguesa. Nesse decreto-lei, em que se aprovam as bases gerais do programa de medidas económicas de emergência, refere-se que o Conselho da Revolução havia assinalado «a deficiente utilização da capacidade produtiva do país em recursos humanos e materiais, acompanhada de redução do nível de investimento, o crescente desequilíbrio da balança de pagamentos e a persistência da pressão inflacionista». Para dar remédio a essa situação e para «reconstruir a economia por uma via de transição para o socialismo» definem-se algumas orientações gerais em que se destaca a enunciada na alínea d): «Deverão ser completados os passos já dados no sentido da nacionalização dos sectores básicos da actividade económica (indústria, transportes e comunicações)».

Com efeito, a 16 de Abril, os decretos-leis n. ${ }^{\circ}$ 205/A, B, C, D, E, F, G/75 publicados no Diário do Governo, 1. ${ }^{a}$ série, n. ${ }^{\circ}$ 89, nacionalizam as seguintes empresas: Sacor, Petrosul, Sonap, Cidla, Companhia dos Caminhos de Ferro Portugueses, Companhia Nacional de Navegação, Companhia Portuguesa de Transportes Marítimos, Transportes Aéreos Portugueses, Siderurgia Nacional, Aliança Eléctrica do Sul, Companhia Eléctrica do Alentejo e Algarve, Companhia Eléctrica das Beiras, Companhia Hidroeléctrica do Norte de Portugal, Companhias Reunidas Gaz e Electricidade, Companhia Portuguesa de Electricidade, Eléctrica Duriense, Empresa Hidroeléctica do Coura, Empresa Hidroeléctrica da Serra da Estrela, Empresa Insular de Electricidade, Hidroeléctrica do Alto Alentejo, Hidroeléctrica Portuguesa, Sociedade Eléctrica do Oeste, União Eléctrica Portuguesa.

Esta série de nacionalizações efectuadas a 16 de Abril nos sectores básicos da economia correspondia, nas suas linhas 
gerais, ao programa do P.C.P. Este partido, logo a 17 de Abril, define a sua posição face às nacionalizações do seguinte modo:

«À histórica decisão do Conselho da Revolução, logo à raiz da sua criação, de nacionalizar a banca e os seguros, sucederam-se agora outras medidas de largo alcance destinadas a enfrentar no imediato os difíceis problemas herdados do fascismo e a rasgar um novo caminho no futuro do nosso povo.

E imprescindível e urgente que todos nos capacitemos da envergadura das medidas agora promulgadas pelo Governo Provisório e do que elas representam e implicam para a vida dos portugueses. A base monopolista da economia portuguesa, herdada do fascismo, foi irreversivelmente atingida nos seus fundamentos e uma nova fase transitória entre duas formações sociais opostas se iniciou.

A nacionalização dos sectores básicos da economia nacional veio trazer à luz do dia o grau extremo da concentração de riquezas operada sob o fascismo» $\left({ }^{28}\right)$.

Repare-se que as nacionalizações são decididas e saudadas em pleno período eleitoral para a Assembleia Constituinte. Ainda a 23 e 24 de Abril, o Governo irá nomear comissões administrativas para as empresas Indústria Nacional Alimentar e Cimentos de Leiria, baseado no decreto-lei n. ${ }^{\circ} 660 / 74$ de 25 de Novembro.

Essa política de intervenção nas empresas através da exoneração de corpos gerentes e da nomeação de comissões administrativas irá continuar a 5 de Maio de 75 desta vez tendo por objecto as empresas rodoviárias tais como: Empresa de Viação Cernache, Empresa de Transportes Zêzere, Empresa de Viação e Comércio de Alenquer, Cooperativa Lisbonense de Chauffeurs, Auto Viação Bucelense, A. B. Fernandes, Empresa de Viação de Manteigas, Auto Confiança Penamacorense, Catarino e Lopes, José Cunha Direito, Antunes e Dilreu, José Martins Póvoa e Centro, Mendes e Marques, Transportadora Central da Madre de Deus, Transportes de Carga Jacinto Cotrina, Empresa Rádio Táxis Neto, Empresa de Transportes Flamingauto, António Correia e Correia, Táxis Pérola do Bairro da Encarnação, Auto Táxis Nunauto, Auto Transportadora da Ponte de Sor $\left({ }^{29}\right)$.

Por outro lado, a política de nacionalizações dos sectores básicos da economia irá conhecer uma segunda fase que se inicia pela nacionalização de várias empresas ligadas à actividade cimenteira tais como: CISUL, CINORTE, Empresa de Ci- *(**)

(28) Editorial do Jornal Avante de 17 de Abril de 1975.

$(* *)$ Diário do Governo, 1.a série, n. ${ }^{\circ} 103$ de 5 de Maio de 75. 
mentos de Leiria, Companhia de Cimentos Tejo, Companhia de Carvões e Cimentos do Cabo Mondego, Sagres, Cibra ( ${ }^{(\mathrm{so})}$.

O mesmo Diário do Governo insere o decreto-lei n. ${ }^{\circ}$ 221-B/75 que nacionaliza empresas da indústria de celulose: Companhia Portuguesa de Celulose, Sociedade Industrial de Celulose, Celulose do Tejo, Celulose do Norte e Celulose do Guadiana.

A 13 de Maio é a vez das sociedades ligadas ao sector dos tabacos serem nacionalizadas. Será o caso de A Tabaqueira, Empresa Industrial de Tabacos, Fábrica de Tabacos Micaelense, Empresa Madeirense de Tabacos, com a excepção das cotas pertencentes a estrangeiros, o que aliás foi uma constante das medidas que estamos a analisar.

O decreto-lei n. ${ }^{\circ} 203-\mathrm{C} / 75$ de 15 de Abril havia no entanto referido também o sector dos transportes. Por consequência, a 5 de Junho, é nacionalizada a Sociedade Metropolitano de Lisboa $\mathrm{e}$ as empresas de transportes colectivos de passageiros pertencentes aos seguintes grupos: João Belo, Claras, Cernache, Eduardo Jorge, Transsul (31).

Estas medidas caracterizaram a actividade do IV Governo Provisório no domínio económico. Durante mais algum tempo haverá ainda nacionalizações ou intervenções mas sem a sequência e a importância política ou económica gerais das acima descritas. O V Governo Provisório que toma posse a 8 de Agosto ainda tomará algumas medidas dessa natureza mas a sua breve existência reduziu a sua amplitude e execução. Por fim, em Setembro de 1975, com a tomada de posse do VI Governo Provisório da Presidência do Almirante Pinheiro de Azevedo, o Partido Socialista e o Partido Popular Democrático entendem-se para porem fim à onda de nacionalizações.

O VI Governo Provisório continuará no entanto com a transferência de propriedade do Alentejo dentro do processo da Reforma Agrária.

Assinale-se que os aspectos agrários da política económica do período pré-constitucional tiveram assinalável importância e contribuiram para caracterizar o ano de 1975 como um momento de intensa colectivização das actividades económicas em Portugal.

O Estado português, enfraquecido politicamente e momentaneamente pela descolonização e pela revolução, estendia

$\left.{ }^{(30}\right)$ Decreto-Lei n. ${ }^{\circ}$ 221-A/75, Diário do Governo, $10^{a}$ série, $1 .^{\circ}$ suplemento, $n .^{\circ} 107$ de 9 de Maio de 1975.

(n) Decretos-Leis 210-A e C/75 publicados no Diário do Governo, l. ${ }^{a}$ série, n. ${ }^{\circ} 129$ de 5 de Junho de 75. 
a sua intervenção ao domínio económico como que a haurir forças para o seu renascimento em regime de democracia política.

\section{Conclusão}

A intervenção militar do M.F.A. caracterizou-se pela ruptura com a indiferença secular das Forças Armadas face ao tipo de regime político interno (monarquia na sua forma constitucional ou ditatorial; república parlamentar ou presidencialista; Estado Novo e Estado Social) e pelo empenhamento no estabelecimento de um regime político de democracia política pluralista.

Esta opção da instituição militar deveu-se a vários factores, desde a necessidade de encontrar um modelo político que permitisse a gestão autónoma dos conflitos sociais até à própria luta institucional que se desenvolveu entre organismos frentistas revolucionários e os aparelhos partidários.

Após o recenseamento eleitoral de Dezembro de 1974 que elevou o número de votantes para perto dos seis milhões e a participação de mais de noventa por cento desse universo nas eleições para a Assembleia Constituinte, o regime de partidos estabeleceu as suas bases que ainda hoje vigoram.

Pelo seu lado, o M.F.A. - autêntica metamorfose da instituição militar - conseguiu introduzir, no II Pacto M.F.A.-Partidos de Fevereiro de 1976, a consagração da eleição directa para Presidente da República. Pode-se dizer que a eleição directa de um general para a Presidência da República tem constituído o essencial da estratégia política da instituição militar no período em análise.

Com efeito, as duas eleições presidenciais já efectuadas caracterizaram-se por uma disputa entre vários militares com concepções diferentes, quer sobre os melhores projectos de sociedade para Portugal, quer sobre as características das Forças Armadas no contexto nacional. Assim, em 1976, tivemos no fundo uma disputa entre Ramalho Eanes e Otelo, e, em 1980, entre Ramalho Eanes e Soares Carneiro. Com estas eleições tratou-se de escolher, por sufrágio universal, o militar que comandaria as Forças Armadas e que imprimiria a influência sublimada da instituição militar na evolução do regime democrático.

Do mesmo passo, permitia-se a existência de um militar com singular força política derivada do sufrágio universal e directo e que estaria assim em melhores condições para subordinar as Forças Armadas ao poder político democrático. 


\section{Revoltas e Revoluções}

A preferência do M.F.A. por um regime democrático foi assim secundada pela própria instituição militar embora por motivos nem sempre coincidentes mas todos conducentes ao fortalecimento do regime de liberdades públicas em que vivemos.

A revolução do 25 de Abril foi o meio provocado pela instituição militar para se atingir certos objectivos nacionais de alternativa, pois os objectivos fixados pelo anterior poder político revelaram-se inadequados.

Acresce que num outro espaço das Forças Armadas - mais exactamente em certas instituições de ensino superior - desenvolveu-se, paralelamente, a elaboração de um conceito alargado de Defesa Nacional por cujos critérios se deveria avaliar a bondade de algumas situações governamentais já que quase tudo, na actividade política, pode ser aferido numa perspectiva de «poder nacional». Deste modo o sistema político estaria sempre sob a avaliação dos peritos em estudos de situação estratégica. Esse conceito alargado de Defesa Nacional pretende também introduzir um elemento perturbador em qualquer regime democrático qual seja o de «inimigo interno», cuja aplicação se apresenta pelo menos arbitrária, e sempre baseada numa expansão da natureza policial de qualquer regime.

Um outro factor de crescimento planificado da influência militar no sistema político deriva das atribuições que podem caber às Forças Armadas na chamada «Gestão das Crises». Contrariamente à anterior concepção «alargada» de defesa nacional feita para permitir uma influência permanente do critério estratégico, já a «gestão das crises» aparece como meio extraordinário de fazer face a uma emergência. Em ambos os casos trata-se de doutrina, por enquanto confinada a certos meios militares e aos auditores do I.D.N., mas revelando o aparecimento de outras abordagens sobre as relações entre as Forças Armadas e o regime político democrático.

As relações entre as Forças Armadas e o regime político democrático não podem no entanto ser perspectivadas em abstracto, ou através de um mero discurso institucional, como $\mathrm{o}$ atrás ensaiado.

O papel da instituição militar na nova era marcada pelo 25 de Abril terá de ser estudado tendo em conta os factores de continuidade e de ruptura introduzidos nas Forças Armadas pelo derrube da ditadura, pela descolonização e pela implantação em Portugal de um regime de democracia política. E o problema militar português só ficará resolvido quando às Forças Armadas forem atribuídas missões - nacionais ou internacionais - de prestígio assegurado, que lhes fixem uma nova natureza, alterada irreversivelmente com o 25 de Abril de 1974, mas ainda não preenchida ou revelada. 


\section{FONTES}

\section{Testemunhos orais}

Alves, Tenente-Coronel Vítor

Brás, Coronel Costa

Charais, General Franco

Durão, Brigadeiro Ricardo

Gomes, General Costa

Machado, Dr. Alberto

Spínola, General António de

II. Documentos

Boletim do Movimento das Forças Armadas - 24 números de 9 de Setembro de 1974 a 25 de Julho de 1975.

Boletim do Ministério do Trabalho de 15 de Março de 1976.

Circular do Estado-Maior das Forças Armadas datada de 27

de Maio de 1974, sem classificação.

Carta de Octávio Pato ao Secretariado do Comité Central do Partido Comunista Português, exposta no Pavilhão dos Desportos de Lisboa em Maio de 1981, na Exposição Comemorativa dos 60 anos do P. C. P.

Diário do Governo, $1 .^{a}$ série, anos de 1974, 1975 e $1^{\circ}$ trimestre $^{\circ}$ a 3 de Abril de 1976. de 1976.

Diário da Assembleia Constituinte de 3 de Junho de 1975

Ficheiro cronológico abrangendo o período de Abril de 1974 a Dezembro de 1975 (cerca de duas mil e quinhentas fichas) elaborado no âmbito do Projecto de Investigação $B$ da Faculdade de Ciências Humanas da Universidade Católica Portuguesa.

Lista onomástica de protagonistas de acontecimentos do período inicial da revolução (cerca de sete mil nomes) elaborado no âmbito do Projecto de Investigação $B$ da Faculdade de Ciências Humanas da Universidade Católica Portuguesa.

Maio de 1974.

Nota Pastoral do Episcopado Português, distribuída a 4 de

Relatório de Actividades do Delegado da Junta de Salvação Nacional no ex-Ministério das Corporações e Segurança Social.

Relatórios das Comissões de Inquéritos aos acontecimentos do

28 de Setembro, do 11 de Março e do 25 de Novembro.

Relatório da Comissão Inter-Ministerial para a análise da problemática das empresas em auto-gestão, Ministério das Finanças, 1980.

Relatório da operação Fim-Regime, elaborado pelo Capitão Salgueiro Maia para a Escola Prática de Cavalaria a 29 de Abril de 1974.

III. Periódicos

A. Quotidianos — período entre 25 de Abril de 74 e 25 de Abril de 76.

A Capital

Comércio do Porto

Diário do Alentejo

Diário de Lisboa 
Diário de Notícias

Diário Popular

Jornal de Notícias

Primeiro de Janeiro

B. Semanários - período entre 25 de Abril de 74 a 25 de Abril de 76.

Avante (1.® número a 17 de Maio de 74).

Expresso

O Jornal (1.® número a 2 de Maio de 1975)

A Ordem

Portugal Socialista (desde o n. ${ }^{\circ}$ de Maio de 74)

Povo Livre (1. ${ }^{\circ}$ número a 15 de Agosto de 74)

Voz Portucalense

\section{Bibliografia}

Almeida, Dinis de, Origens e Evolução do Movimento dos Capitães, Lisboa, Ed. Sociais, 1976.

Almeida, Dinis de, Ascenção e Queda do M.F.A., Lisboa, Ed. Sociais, s.d.

Arroz, Maria Emília, et. al., As Eleições Legislativas - Algumas Perspectivas Regionais, Lisboa, Livros Horizonte, s.d.

Antunes, José Freire, O Segredo do 25 de Novembro, Lisboa, Ed. Europa-América, 1980 .

Banazol, Ten. Cor., A Origem do M.F.A., Lisboa, Prelo, 1974.

Banazol, Ten. Cor., Os Capitães, Lisboa, Prelo, 1974.

Banazol, Ten. Cor., A Tarde dos Generais, Lisboa, Prelo, 1975.

Banazol, Ten. Cor., Os Capitães Generais e os Capitães Políticos, Lisboa, Prelo, 1976.

Burchett, Wilfred, Portugal depois da Revolução dos Capitães, Lisboa, Seara Nova, 1975.

Caetano, Marcelo, Depoimento, Rio de Janeiro, Distrib. Record, 1974.

Caetano, Marcelo, O 25 de Abril e o Ultramar, Lisboa, Verbo, 1977.

Carneiro, Francisco Sá, Por uma Social Democracia Portuguesa, Lisboa, Dom Quixote, 1965.

Carvalho, Otelo Saraiva de, Alvorada em Abril, Lisboa, Bertrand, 1977.

Carvalho, Otelo Saraiva de, Cinco Meses que Mudaram Portugal, Portugália, 1975.

Clemente, Duran, Elementos para a Compreensão do 25 de Novembro, Lisboa, Ed. Sociais, 1976.

VII Congresso do P.C.P., Lisboa, Ed. Avante, 1974.

Cunha, Luz, Arriaga, Kaulza, Rodrigues, Bettencourt, Marques, Silvino Silvério, Africa, a Vitória Traída, Lisboa, Ed. Intervenção, 1977.

Cunha, Silva, O Ultramar, a Nação e o 25 de Abril. Coimbra, Atlântida Ed., 1977.

Correia, Natália, Não Percas a Rosa, Lisboa, Publ. Dom Quixote, 1968.

Correia, Ramiro, M.F.A. Dinamização Cultural, Lisboa, Bibl. Ulmeiro, 1977.

Cunhal, Álvaro, Rumo à Vitória, Porto, Ed. Opinião, 1974.

Cunhal, Álvaro, A Revolução Portuguesa, Lisboa, Publ. Dom Quixote, 1975.

A Democracia Cristã em Portugal. Três Congressos do C.D.S., s.L, Democracia 76, s.d..

Diário de uma Revolução, Lisboa, Ed. Mil Dias, 1978. 
Downs, Charles, «Comissões de Moradores" and Urban Struggle in Revolutionary Portugal, comunicação policopiada apresentada no II International Conference Group on Modern Portugal, Univ. of New Hampshire, Junho 79.

Dossier da 2. (B República, 2 vols., Lisboa, ed. Fernando Ribeiro de Melo led. Afrodite, 1976.

Ferreira, José Medeiros, Aspectos Internacionais da Revolução Portuguesa, comunicação policopiada apresentada no II International Conference Group on Modern Portugal, Univ. of New Hempshire, Junho 1979.

Ferreira, José Medeiros, Do Código Genético no Estado Democrático, Lisboa, Contexto, 1981.

Ferreira, José Medeiros, Ensaio Histórico sobre a Revolução do 25 de Abril, Lisboa, Imprensa Nacional, 1983.

Fonseca, A. Fernandes da, A Revolução Portuguesa à Luz da Psicologia, Porto, s.e., 1967.

Prémontier, Jacques, Portugal: Os Pontos nos ii, Lisboa, Moraes Ed., 1976.

Gaspar, Jorge e Vitorino, Nuno, As Eleições do 25 de Abril. Geografia e Imagem dos Partidos, Lisboa, L. Horizonte, 1976.

Gomes, Francisco Costa, Sobre Portugal. Diálogos com Alexandre Manuel, Lisboa, Ed. A Regra do Jogo, 1979.

Gomes, Varela, Sobre os Golpes Contra-Revolucionários de 11 de Março e de 25 de Novembro de 1975, Lisboa, s.e., 1980.

Graham, Makler, Contemporany Portugal: The Revolution and its Antecedents, Austin, University of Texas Press, 1979.

Harvey, Robert, Portugal, Birth of a Democracy, Londres, Mac Millan Press, 1978.

Leis Fundamentais da República Portuguesa, Lisboa, Imprensa Nacional - Casa da Moeda, 1974.

Lemos, Viana de, Duas Crises, Lisboa, Ed. Nova Génese, 1977.

Lourenço, Eduardo, os Militares e o Poder, Lisboa, Arcádia, 1975.

Lourenço, Eduardo, O Labirinto da Saudade, Lisboa, Publ. Dom Quixote, 1978.

Marques, A. H. Oliveira, História de Portugal, vol. III, Palas Ed., 6.a ed., 1981.

Mc Govern, George, Revolution into Democracy: Portugal after the Coup, Relatório para o Committee on Foreign Relations, United States Senate, Aug. 76.

Miranda, Jorge, A Constituição de 1976. Formação, Estrutura, Princípios Fundamentais, Lisboa, Livr. Petrony, 1978.

Morais, Manuel Tito de, O "Portugal Socialista» na Clandestinidade, Lisboa, Ed. Portugal Socialista, 1977.

Mota, José Gomes, A Resistên cia, Lisboa, Ed. Jornal Expresso, 1976.

Osório, José Sanches, O Equívoco do 25 de Abril, Lisboa, Ed. Intervenção, 1975.

Partido Popular Democrático, Notas sobre a Origem, Actividades até ao I Congresso Nacional, Lisboa, Ed. da Comissão Política Distrital de Lisboa do P. P. D., Maio de 75.

Pereira, António Maria, A Burla do 28 de Setembro, Lisboa, Bertrand, 1966.

Rego, Raul, Militares, Clérigos e Paisanos, Lisboa, Perspectivas e Realidades, 1981.

Rodrigues, Avelino et al., Portugal depois de Abril, Lisboa, Intervenção, 1976.

Rodrigues, Avelino et. al., Abril nos Quartéis de Novembro, Lisboa, Bertrand, 1979. 


\section{Revoltas e Revoluções}

Santanché ${ }_{\mathrm{K}}$ Gioacchino, Uma Revolução Falhada, Lisboa, Perspectivas e Realidades, 1980.

Santos, Maria de Lourdes Lima, Lima, Rodrigues Pires de, Ferreira, Vítor Matias, $O 25$ de Abril e as Lutas Sociais nas Empresas, Porto, Ed. Afrontamento, 1976.

Saraiva, José António, Do Estado Novo à Segunda República, Lisboa, Bertrand, 1974.

Soares, Mário, Democratização e Descolonização, Lisboa, Ed. Dom Quixote, 1975.

Soares, Mário, Portugal, Que Revolução?, Lisboa, Perspectivas e Realidades, 1976.

Spínola, António de, Ao Serviço de Portugal, Lisboa, Bertrand, 1976.

Spínola, António de, País sem Rumo, s.l., Scire, 1978. 